\title{
Transformational Leadership Theory and Exploring the Perceptions of Diversity Management in Higher Education
}

\author{
Melissa Brown \\ Northwestern Oklahoma State University \\ Roger S. Brown \\ Northwestern Oklahoma State University
}

\author{
Ankur Nandedkar \\ Millersville University
}

With the introduction of diversity policies and diversity management programs, the intent of the top administration and what is enforced at the lower levels may vary. This paper examines underlying factors that would impact the perception of the established diversity management program by lower-level employees in tertiary education institutions. We will then outline how transactional leadership and transformational leadership of the supervisors may impact the perceptions of diversity management in higher education. We will conclude by focusing on areas for future research in diversity management within the higher education context.

Keywords: Diversity, Leadership, Higher Education

\section{INTRODUCTION}

The trend towards globalization and the demographic shift has resulted in workplace diversity being much more than merely a buzzword that companies use in their recruitment campaigns. The literature of workplace diversity has investigated environmental factors such as legal mandates, resource dependencies as predictors on the firm's decisions to adopt practices conducive to managing diversity in the workplace (Ng \& Sears, 2012). Firms emphasize on diversity management because of the "business case" for diversity; it may be instrumental in forging a competitive advantage, improving a firm's innovative capabilities and overall performance (Saxena, 2014; Zikic, 2015; Lambert, 2016). Since technological advancements are one of the foremost factors contributing to globalization, global workers are required to be sophisticated and must possess adaptable technological skills as well as ability to interact with people from across the globe (Brown-Glaude, 2009).

Diversity management is a strategic issue for organizations. Diversity can be defined as the process or strategy of promoting the perception, acknowledgment, and implementation of diversity in organizations and institutions (Deshwal \& Choudhary, 2012). The College and University Professional Association for Human Resources found that minority representation in tertiary institutions reflects that of private 
industries. Only $7 \%$ of administrative positions were held by black, $3 \%$ by Hispanic or Latinos, $2 \%$ by Asian, and $1 \%$ other race or ethnicity the remaining $86 \%$ of administrators were white similar to that of $87 \%$ of private industries (Seltzer, 2017). More progress is needed to foster diversity and inclusion programs and its implementation in higher education, and the process should begin from the executive level. The leadership style of the president belonging to a tertiary institution impacts the diversity program of colleges and universities (Tierney, 1991).

To address the question related to the impact of leadership on diversity, Kezar and Eckel (2008) investigated the role of university president's transactional and transformational leadership styles on campus-wide diversity efforts and found that both of the leadership styles were critical to campus diversity. However, more research is needed to understand the dynamics of these leadership styles, and when used by supervisors at each level in the institutions, its impact on perceptions of diversity management of lower-level employees. To this end, the paper investigates the influence of transactional and transformational leadership styles of supervisors across various levels in higher education institutions, on the diversity management perceptions of lower-level employees.

\section{LITERATURE REVIEW}

Burns (1978) introduced the concept of transforming and transactional leadership. Building on the work, Bass (1985) integrated the concepts to the study of formal organizations and investigated the psychological phenomenon associated with transformational and transactional leadership. Bass (1985) is credited for coining the term 'transformational leadership'.

Transactional leadership style is characterized by leaders emphasizing compliance on followers with the use of both rewards and punishment. These leaders exercise authority and power in the firm, and they are also known for prioritizing tasks assignments, and monitoring work standards (Bass, 1985; Sashkin, 2004). However, transformational leaders motivate and inspire the followers to achieve extraordinary outcomes, and simultaneously develop a follower's leadership potential (Bass, 1985; House \& Shamir, 1993; Sashkin, 2004). Research has shown that transformational leadership contains four main dimensions: idealized influence, inspirational motivation, intellectual stimulation, and individualized consideration (Avolio, Bass, \& Jung, 1999). These leader attributes are critical as they stimulate followers to go above and beyond their capabilities for excellent performance outcomes (Judge \& Piccolo, 2004) reconsider their fundamental values and a willingness to sacrifice their own interests for collective good (Finkelstein \& Hambrick, 1996; Kark \& Shamir, 2013; Howell \& Shamir, 2005). Both transformational and transactional leadership styles are correlated with the leader's moral and ethical orientation. Transformational leaders are more inclined with doing what is "morally right" and protecting the rights and dignities of individuals, and even though transactional leaders share this trait with transformational leaders, they are more inclined toward utility maximization (Aronson, 2001; Groves \& LaRocca, 2010). Transformational leaders are known to exhibit higher perceived integrity (Aronson, 2004), greater moral development (Bass \& Steidlmeier, 1999) and more ethical behavior (Aronson, 2004; Brown \& Trevino, 2006). The diversity climate is the shared perceptions by the institution or workgroup employees in terms of the degree in which the organization socially integrates historically disadvantaged, discriminated or underrepresented employees and encourage impartiality in employee policies (Mor Barak, Cherin, \& Berkman, 1998). Since moral development and diversity climate have been linked (DiTomaso \& Hooijberg, 1996; Wilson, 2009), transformational leaders are inclined to foster the organizational climate focusing on diversity, inclusivity, and social responsibility. Transformational leaders can persuade followers that managing diversity is the right thing to do and that diversity is not just a matter of legal compliance (Leonard \& Grebler, 2006).

Leadership styles have been linked to strategic decision-making and leader's emphasis on different types of justice (Tatum, Eberlin, Kottraba, \& Bradberry, 2003; Eberlin \& Tatum, 2008). In particular, transformational leaders underscore social justice while transactional leaders favor procedural justice. Transformational leadership supports protecting the welfare of all individuals in society and ensuring the fair treatment of all people in their actions (Hood, 2003; Tatum, Eberlin, Kottraba, \& Bradberry, 2003). 
In this regard, transformational leaders make efforts for managing diversity because it has the potential to enhance the well-being of the organization and its members. Transaction leaders, alternatively, are focused on following the rules so their approach to diversity management may be driven with the necessity to abide by the laws (Hood, 2003).

Scholars have suggested that in order to promote diversity and inclusivity within the context of higher education, transformational leaders are necessary (Tierney, 1991; Aguirre Jr \& Martinez, 2006), while others suggest that transactional leaders are better suited for the higher education environment because of the prevalent bureaucracy (Birnbaum, 1992). However, empirical evidence supporting either claim is scant (Kezar \& Eckel, 2008).

Within the context of higher education, studies have investigated the impact of transformational and transactional leadership style. For instance, Bensimon, Neumann, and Birnbaum (1989) argued that in colleges and universities, transactional leadership is likely to be more effective than transformational leadership because of the ambiguity in goals and decentralized structures. According to Bensimon, Neumann, and Birnbaum (1989), transactional theories focus on social exchange, which is more reflective of leadership at campuses. They further noted that "College and university presidents can accumulate and exert power by controlling access to information, controlling the budgetary process, allocating resources to preferred projects, and assessing major faculty and administrative appointments" (Bensimon, et. al., 1989 , p. 39), but they democratically execute the process so that their image of exercising authority while valuing participative decision making is strengthened. This process is also reflective of normative organizational values. The rationale used by Bensimon, Neumann, and Birnbaum (1989) was that leadership styles should be adapted according to the organizational structure.

A few studies have echoed the argument that transactional leadership is more suited to college campuses and have investigated the degree to which leaders use transformational versus transactional approaches. The study by Wolverton and Gmelch (2002) investigated leadership styles of deans and reported that hierarchical structure, reward systems, and tenure promotion process were conducive to transactional leadership. They also supported the notion that deans utilized transactional as well as transformational to be successful. Deans were found to provide direction and empowerment to others, which is consistent with the transformational leadership style. In addition, the study found that leadership style varied by the type of institution; leaders in research-oriented institutions used transactional leadership while leaders within teaching-focused state institutions favored transformational leadership style. Similarly, Bensimon (1993) examined the differences in transactional and transformational styles of presidents and found that a blend of two approaches was effective. In particular, transformational leadership was shown to increase morale and build satisfaction among faculty and staff; while transactional leadership was instrumental in developing the infrastructure of the organization, its capacity, and resources.

In a quest to determine which leadership is ideal to drive institutional change towards diversity and inclusion, Adserias, Charleston, and Jackson (2017) reviewed the literature on forms of diversity agenda, paradigms of change and leadership style, and synthesized the results from ten cases to provide insights. In particular, their study concluded there is no best leadership style to promote diversity on college campuses, but leaders have often used both transactional and transformational styles in a manner that is a reflection of the full range of leadership model (Bass \& Riggio, 2006; Kezar \& Eckel, 2008). The study also emphasized that successful leaders carefully analyze several contextual factors before deciding whether to exhibit transformational or transactional leadership.

Some studies suggest that leadership around certain issues require more emphasis on transformational than transactional style. For instance, Aguirre Jr and Martinez (2006) hypothesized that leaders who seek to diversify college campuses would achieve desired results if they utilize transformational leadership by empowering and motivating others, developing trust, and working to transform the values and preferences of organizational culture. Their argument assumed that major change requires people to rethink their values, and transformational leadership style can bring this change while transactional is not suited for such situations. In addition, Al-husseini and Elbeltagi (2018) have reported that transformational leadership with the context of higher education promotes knowledge sharing and fosters the culture of 
trust, cooperation, and encouragement. All these factors are shown to be conducive to diversity (Downey, van der Werff, Thomas, \& Plaut, 2015).

An overall analysis of the research results have been mixed, and more research is required to understand how transactional and transformational leadership styles of supervisors at all levels affect the perceptions of lower-level employees regarding diversity management practices of the organization. In the next section, we develop the hypotheses for the study, which is followed by the discussion and conclusion.

\section{THEORY AND PROPOSITIONS}

In this paper, the authors will focus on tertiary institutions, which for the sake of this paper includes colleges and universities granting associates degrees, bachelor's degrees, and graduate degrees. Despite globalization and shifts in the demographics, there are locations in the US that have populations that reflect heterogeneity and homogeneity. Demographic populations that reflect heterogeneity tend to be fairly diverse in terms of race and ethnicity, while populations that reflect homogeneity have very low levels of diversity in terms of race and ethnicity. In this paper, locations that reflect heterogeneity in the demographics have a racial or ethnic minority population percentage at or above the US averages. Also, in this paper, the locations that have a population that reflects homogeneity in the demographics consisting of racial and ethnic minorities' population percentages below the US average.

In line with representative bureaucracy theory, the individuals that make policy and strategy decisions for the organization tend to use their discretion to ensure that these policies and strategies represent the values of those individuals (Meier, Wrinkle, \& Polinard, 1999). Therefore, if the individuals making policy and strategic decisions are a reflection of the representation of the local population, it serves that they will tend to make decisions benefitting that population (Thielemann \& Stewart Jr, 1996). The emphasis on diversity management may be lower in locations where there is a less diverse population. Locations in the US where the local population is relatively homogeneous, the impulse for diversity management may be lower than most metropolitan areas, and thus diversity management may be less impactful because of the lower impetus (Pitts, 2009). Representative bureaucracy promotes the inclusion of various groups by encouraging the presence of a representative for the various interest groups during the planning and development stages of the formation of policies (Denhardt \& DeLeon, 1995; Kim \& Park, 2017). In locations with a homogenous population, diversity management policies and strategies exist for a variety of reasons similar to areas with a more heterogeneous population. Some of the reasons encouraging diversity management initiatives are governmental regulations and normative pressures (Konrad, Yang, \& Maurer, 2016) and institutional pressures (Konrad, Yang, \& Maurer, 2016) such as accreditation bodies and best practices recommended by professional associations (Clemons, 2013). Organizations vary in the level they adhere to institutional pressures (Oliver, 1991). It is possible that majority members (not a female or minority) fearing adverse resource control matters may show hostility with the systematic relative increase in minorities and women attaining senior-level positions (Kossek, Markel, \& McHugh, 2003). The inability to attain an adequate level of proportional representation can impact experiences of dominance, imbalance, balance, or tokenism by employees (Kanter, 1977).

In line with representative bureaucracy theory and the possible lower impetus in a relatively homogenous location as stated by Pitts (2009) diversity management programs and the impact on the diversity, climate may be perceived as being less effective in terms of the perceptions of minority employees in these locations than in locations with a more heterogeneous population. If there is a lower impetus on diversity management strategies and policies, then there could also be an impact on the level of adequate support and career advancement for female employees. In congruence with the research done by McKay, Avery and Morris (2009) the impact on the diversity climate is being considered as a means of evaluating the effectiveness of the diversity management system. Therefore, one may surmise that the diversity management programs impact on diversity climate may be perceived as being less effective in terms of the perceptions of female employees in locations with a more homogenous population than in 
locations with a more heterogeneous population. The following propositions have been developed consistent with the arguments above.

P1a. In a tertiary institution with a homogenous local population diversity management practices may have a lesser positive impact on the diversity climate from the perception of all the employees than those employees located in tertiary institutions located in a more heterogeneous populated area.

P1b. In a tertiary institution with a homogenous local population diversity management practices may have a lesser positive impact on the diversity climate from the perception of minority employees than those minority employees located in tertiary institutions located in a more heterogeneous populated area.

P1c. In a tertiary institution with a homogenous local population diversity management practices may have a lesser positive impact on the diversity climate from the perception of female employees than those female employees located in tertiary institutions located in a more heterogeneous populated area.

As mentioned above transformational leaders focus on changing the moral thought process of their employees/followers and raising the overall standards of morality and motivation (Burns, 1978; Bass, 1985; Kezar \& Eckel, 2008). Transactional leaders tend to utilize reciprocation with their employees that involves using contingent rewards to negotiate or bargain to accomplish the organization's goals (Burns, 1978; Bass, 1985; Kezar \& Eckel, 2008). Bass and Avolio (1997) proposed that a combination of the transformational and transactional leadership styles could be utilized by the organization's leadership. This combination of leadership styles Bass and Avolio (1997) referred to as "full-range leadership model" (Kezar \& Eckel, 2008, p. 382). This combination used by organization leaders was found to be effective (Wolverton \& Gmelch, 2002; Bensimon, 1993).

For tertiary institutions located in a more homogeneous population, the diversity management system may be hampered by the various elements mentioned above. These elements include aspects of representative bureaucracy theory (Pitts, 2009), variances in the organization adhering to normative and institutional pressures (Oliver, 1991), majority members fearing adverse resource control (Kossek, Markel, \& McHugh, 2003) and inadequate proportional representation (Kanter, 1977). Transactional style of leadership on its own by tertiary institutions located in homogeneous populated areas may not be effective in ensuring an effective diversity management system. To overcome the various elements mentioned above, hampering diversity management programs for tertiary institutions located in homogeneous populated areas requires significant elements of transformational leadership.

Bensimon, Neumann, and Birnbaum (1989) asserted that due to the nature of colleges and universities (tertiary institutions) a transactional leadership style might be more suited and effective in that type of organization as opposed to other organizations. Kezar and Eckel (2008) stated that some university presidents encountered some resistance when using transformational strategies that promoted diversity and attempted to diversify the demographics of their professoriate. Wolverton and Gmelch (2002) in looking at the administration of university deans, found that the structure of the tertiary institutions also favored a transactional leadership style. Given the nature or structure of these tertiary institutions in homogeneous locations, a transformational leadership style on its own may not be effective in ensuring an effective diversity management system. Employee's perception of a high level of management's commitment to enact and adhere to diversity policies as part of the organization's strategic plans is correlated with the success of the diversity policies (Cox, 1993; Kossek \& Lobel, 1996; Thomas \& Ely, 1996). The full range leadership style (Kezar \& Eckel, 2008) by the top administration may have a more significant impact on the effectiveness of diversity management of these tertiary institutions located in homogeneous populations from the perception of lower-level employees than a predominant transactional leadership style or predominant transformational leadership style by top administration. Consistent with these arguments, the following proposition has been made by the authors. 
P2. In a tertiary institution located in a homogeneous local population if the administration is utilizing the full range leadership style, it would have a more positive impact on the perception of the effectiveness of diversity management practices by lower-level employees than those where top administration is using a transactional or transformational style only.

Human resource diversity management strategies and policies are established at the organizational level, but the social and practical aspects are enacted in the work units' level (Larkey, 1996). In other words, top administration diversity management policies are dispersed to the various department groups towards managing diversity in their workgroups (Kossek, Markel, \& McHugh, 2003). In examining diversity initiatives that occur at the organizational level to positively impact the diversity climate, one must consider the multilevel model for the organization's climate developed by Zohar (2000). Even with diversity initiatives that create a demographic shift, there could be a dilution of these initiatives at the lower and senior levels if they don't have a significant demographic shift thus having only a minor change impact on the existing diversity climate (Kossek, Markel, \& McHugh, 2003). Despite the various policies and procedures at the organizational level the diversity climate at the work unit or group level will be significantly impacted by the manager's or supervisor's execution of those initiatives and preservation of those procedures (McKay, Avery, \& Morris, A Tale of Two Climates: Diversity Climate from Subordinates' and Managers' Perspectives and Their Role in Store Unit Sales Performance, 2009). McKay, Avery, and Morris (2009) also asserted that the supervisors and managers might use discretion in executing these diversity policies and thus there may be variances in the way the policies are executed in each work unit. Managers and supervisors at the lower level within the tertiary institution have a significant impact on the perceptions of employees in regards to the effectiveness of the diversity management system (Bowen \& Ostroff, 2004; Wright \& Nishii, 2007; Nishii \& Mayer, 2009; Ashikali \& Groeneveld, 2015).

Diversity strategies promote demographics shifts in various workgroups including status levels in the workgroups; thus, it creates a different group climate (Kossek, Markel, \& McHugh, 2003). When an organization has a greater impetus on diversity management practices, there is usually a perception of great workgroup performance for employees of color and white employees (Pitts, 2009). Some groups may perceive they obtain greater benefits from an organization's diversity management practices than others (Kim \& Park, 2017). Diversity management is more impactful to minorities than whites (Pitts, 2009). Work-life balance/flexibility and training where women, minorities and non-traditional employees obtain adequate support and are exposed to meaningful development opportunities for career advancement is critical to a diversity management program (Robinson \& Dechant, 1997; Konrad, Yang, \& Maurer, 2016). Kim and Park (2017) while studying public organizations concerning diversity management system and fairness, found that female employees perceived diversity management differently than minority group employees. Despite the differences, there has been research that found the organization's impetus on diversity strategies and policies are of greater importance to racial/ethnic minority groups and women than white male counterparts (Avery \& McKay, 2006). Other research has shown that all groups of employees have a positive job mentality towards the use of diversity management (Choi, 2008; Pitts, 2009; McKay, Avery, Tonidandel, Morris, Hernandez, \& Hebl, 2007).

Valuing differences is important for managers who supervise diverse employees (Pitts, 2009). Diversity management is a primary means in pursuing proper and fair treatment of employees irrespective of gender, race, and ethnicity (Soni, 2000). Diversity management has played an instrumental role to prevent or hamper traditional racial and gender inequalities that were occurring in many organizations (Kim \& Park, 2017). When a workgroup is perceived to be managing diversity in a positive way, women and minorities relate well with other group members, and they all have equal access to the workgroup resources (Kossek, Markel, \& McHugh, 2003). We contend that to enact changes and maintain an effective diversity management system, the supervisors or managers will have to use some levels of transformational leadership.

There is difficulty in executing diversity management goals and initiatives if the employees don't identify or support the diversity practices to be implemented in the organization (Soni, 2000; Kim \& Park, 
2017). Including the adherence to diversity initiatives in the performance evaluations of employees, including those for supervisors and managers may enhance the effectiveness of diversity management (McKay, Avery, \& Morris, 2009). This system can become more effective if unit practices are synchronized with the overall business strategy to attain the goals of the organization (Dulebohn, Molloy, Pichler, \& Murray, 2009; Way \& Johnson, 2005). We contend that supervisors and managers will have to use some levels of transactional leadership style to align the goals and performance evaluations with the diversity management policies. Stemming from these arguments, we have developed the following propositions.

P3a. If a department supervisor or manager uses a full range leadership style in enacting diversity management initiatives at a tertiary institution located in a homogeneous demographic area, there would be a more positive perception of the diversity climate by minority employees than department supervisors or managers employing transformational or transactional leadership style only.

P3b. If a department supervisor or manager uses a full range leadership style in enacting diversity management initiatives at a tertiary institution located in a homogeneous demographic area, there would be a more positive perception of the diversity climate by female employees than department supervisors or managers employing transformational or transactional leadership style only.

\section{DISCUSSION}

This paper extends the already existing research on diversity management and transformational leadership theory. Previous research has reflected the use of transformational leadership (Tierney, 1991; Aguirre Jr \& Martinez, 2006) or transactional leadership (Birnbaum, 1992; Bensimon, Neumann, \& Birnbaum, 1989) to enhance the drive to implement and maintain a diversity management system. Other research has found positive results utilizing a combination of both transformational and transactional leadership (Kezar \& Eckel, 2008; Bensimon, 1993; Wolverton \& Gmelch, 2002; Bass \& Riggio, 2006). Adserias, Charleston, and Jackson (2017) concluded that neither transactional or transformational leadership style was consistently better in terms, ensuring the fulfillment of a diversity agenda. This paper builds on the Kezar and Eckel (2008) work to contend that for a tertiary institution located in homogeneous demographic populations the full range leadership style would be better suited for advancing a diversity management system.

This theory was developed from a conjunction of transformational leadership theory (Bass, 1985) representative bureaucracy (Meier, Wrinkle, \& Polinard, 1999) inadequate proportional representation (Kanter, 1977) and impetus for diversity management programs for locations with a heterogeneous or homogeneous demographic population (Pitts, 2009). The focus is more on tertiary institutions located in homogeneous populations and justifying using the full range leadership style, not just top administrators but also managers and supervisors at these institutions. With managers and supervisors being a key $\operatorname{cog}$ in employee's perceptions of the effectiveness of a diversity management system (Bowen \& Ostroff, 2004; Wright \& Nishii, 2007; Nishii \& Mayer, 2009; Ashikali \& Groeneveld, 2015) we contend they too should utilize the full range leadership style for tertiary institutions located in a homogeneous demographic area.

This theory development provides a basis for data collection, data analysis and the interpretation of the results in regards to the more effective leadership style for a tertiary institution in a homogeneous demographic area for both top administrators, managers, and supervisors. Senior administrators, managers, and supervisors' control of resources and rewards and their influence on the implementation and perceptions of the employees is critical to the effectiveness of a diversity management system for multi-levels within the tertiary institution. 


\section{LIMITATIONS AND FUTURE RESEARCH}

One of the important limitations of this study is that in assessing the effectiveness of a diversity management system, we are focusing on the perceptions of the employees. Distinctions exist between the intended, the actual, and the perception of diversity policies (Wright \& Nishii, 2007; Ashikali \& Groeneveld, 2015). The diversity management system can be strongly influenced by the top administrators and whether or not they are a part of a minority group or the majority group (Ashikali \& Groeneveld, 2015). In accordance with equity theory (Adams, 1963), employees are motivated by equality in the workplace. If an employee perceives inequality, they may adjust their exertions and task with respect to their equity perception (Kim \& Park, 2017). A diversity management system is expected to level the playing field for historically disadvantaged or discriminated groups, but this paper focuses more on the perception of the diversity management system and not on perceived fairness.

Another limitation of this study is the focus has been on the perception of all employees, women, and minorities. To further expand this research, more attention can also be spent on the perception of white male employees. Kim and Park (2017), asserted that in some cases, white employees might perceive diversity management practices may lead to inequitable treatment of them by the organization.

An additional limitation is that there may be other constraints on the diversity management system for various tertiary institutions that may impact the impetus and perception by the employees such as budgetary constraints. Pitts (2009) reflected in his work that presidents of universities do use a significant level of pragmatism in their policies and decision making. Budgetary constraints, for example, may hamper recruitment efforts of tertiary institutions located in homogeneous demographically populated areas to attract the qualified pool of minority groups to apply and work at these locations. The employment of a diversity expert has a positive impact on the organization attaining an effective diversity management program (Konrad, Yang, \& Maurer, 2016). Budgetary constraints may limit the employment of a full-time diversity expert or specialist.

This paper is conceptual, and the authors hope in the future to empirically test this concept within the context of the United States and other countries. A more in-depth look of the specific elements of transformational leadership and transactional leadership that should be combined for the full range leadership style to lead to better management of diversity by top administrators, managers, and supervisors should be explored. This suggested in-depth analysis, in turn, can perhaps provide some insight for diversity management practices for the short and long term.

\section{REFERENCES}

Adams, J. S. (1963). Towards an understanding of inequity. The Journal of Abnormal and Social Psychology, 67(5), 422.

Adserias, R. P., Charleston, L. J., \& Jackson, J. F. (2017). What style of leadership is best suited to direct organizational change to fuel institutional diversity in higher education? Race Ethnicity and Education, 20(3), 315-331.

Aguirre, A. Jr., \& Martinez, R. O. (2006). Diversity Leadership in Higher Education. ASHE Higher Education Report. Volume 32, Number 3. ASHE Higher Education Report, 32(3), 1-113.

Al-husseini, S., \& Elbeltagi, I. (2018). Evaluating the effect of transformational leadership on knowledge sharing using structural equation modeling: the case of Iraqi higher education. International Journal of Leadership in Education, 21(4), 506-517.

Aronson, E. (2001). Integrating leadership styles and ethical perspectives. Canadian Journal of Administrative Sciences, 18(4), 244-256.

Aronson, E. (2004). Ethics and leader integrity: An empirical investigation. In Proceedings of the 9th biannual conference of the international society for the study of work values. New Orleans, LA.

Ashikali, T., \& Groeneveld, S. (2015). Diversity management for all? An empirical analysis of diversity management outcomes across groups. Personnel Review, 44(5), 757-780. 
Avery, D. R., \& McKay, P. F. (2006). Target practice: An organizational impression management approach to attracting minority and female job applicants. Personnel Psychology, 59(1), 157-187.

Avolio, B. J., Bass, B. M., \& Jung, D. I. (1999). Re-examining the components of transformational and transactional leadership using the multifactor leadership questionnaire. Journal of Occupational and Organizational Psychology, 72, 441-462.

Bass, B. M. (1985). Leadership and performance beyond expectations. New York: Free Press.

Bass, B. M., \& Avolio, B. J. (1997). Concepts of leadership. Leadership: Understanding the Dynamics of Power and Influence in Organizations, 3-22.

Bass, B. M., \& Riggio, R. E. (2006). Transformational Leadership. Mahwah, NJ: Lawrence Erlbaum Associates.

Bass, B. M., \& Steidlmeier, P. (1999). Ethics, character, and authentic transformational leadership behavior. Leadership Quarterly, 10(2), 181-217.

Bensimon, E. (1993). New president's initial actions: transactional and transformational leadership. Journal of Higher Education Management, 8(2), 5-17.

Bensimon, E., Neumann, A., \& Birnbaum, R. (1989). Making Sense of Administrative Leadership: The ' $L$ ' Word in Higher Education. Washington, DC: George Washington University Press.

Birnbaum, R. (1992). How academic leadership works: Understanding success and failure in the college presidency. San Francisco, California: Jossey-Bass Inc.

Bowen, D. E., \& Ostroff, C. (2004). Understanding HRM-firm performance linkages: The role of the "strength" of the HRM system. Academy of Management Review, 29(2), 203-221.

Brown, M. E., \& Trevino, L. K. (2006). Ethical leadership: A review and future directions. Leadership Quarterly, 17(6), 595-616.

Brown-Glaude, W. R. (2009). Introduction: Listen to the Submerged Voices -Faculty Agency in a Challenging Climate, Doing Diversity in Higher Education. In W. R. Brown - Glaude, Faculty Leaders Share Challenges and Strategies, (pp. 1-13). New Brunswick, NJ: Rutgers University Press.

Burns, J. M. (1978). Leadership. New York: Harper \& Row.

Choi, S. (2008). Diversity in the US federal government: Diversity management and employee turnover in federal agencies. Journal of Public Administration Research and Theory, 19(3), 603-630.

Clemons, D. C. (2013). Driving diversity within your organization. Public Relations Tactics, $20(1), 8$.

Cox, T. J. (1993). Cultural Diversity in Organizations. San Francisco, CA: Berrett-Koehler.

Denhardt, R. B., \& DeLeon, L. (1995). Great thinkers in personnel management. Classics of Public Personnel Policy, 21-41.

Deshwal, P., \& Choudhary, S. (2012). Workforce diversity management: Biggest Challenge for the 21stcentury Managers. International Journal of Multidisciplinary Research, 2(4), 74-87.

DiTomaso, N., \& Hooijberg, R. (1996). Diversity and the demands of leadership. Leadership Quarterly, $7(2), 163-187$.

Downey, S. N., van der Werff, L., Thomas, K. M., \& Plaut, V. C. (2015). The role of diversity practices and inclusion in promoting trust and employee engagement. Journal of Applied Social Psychology, 45(1), 35-44.

Dulebohn, J. H., Molloy, J. C., Pichler, S. M., \& Murray, B. (2009). Employee benefits: Literature review and emerging issues. Human Resource Management Review, 19(2), 86-103.

Eberlin, R. J., \& Tatum, B. C. (2008). Making just decisions: Organizational justice, decision making, and leadership. Management Decision, 46(2), 310-329.

Finkelstein, S., \& Hambrick, D. (1996). Strategic leadership: Top executives and their effects on organizations. St. Paul, Minnesota: West Publishing Company.

Groves, K. S., \& LaRocca, M. (2010). Leader ethical values as key antecedents to transformational and transactional leadership. In annual meeting of Western Academy of Management. Kona, Hawaii, USA.

Hood, J. N. (2003). The relationship of leadership style and CEO, values to ethical practices in organizations. Journal of Business Ethics, 43(4), 263-273. 
House, R. J., \& Shamir, B. (1993). Toward the integration of transformational, charismatic, and visionary theories. In M. M. Chemers, \& R. Ayman, Leadership theory and research: Perspectives and directions (pp. 167-188). San Diego: Academic Press.

Howell, J. M., \& Shamir, B. (2005). The role of followers in the charismatic leadership process: Relationships and their consequences. Academy of Management Review, 30(1), 96-112.

Judge, T. A., \& Piccolo, R. F. (2004). Transformational and transactional leadership: A meta-analytic test of their relative validity. Journal of Applied Psychology, 89(5), 755-768.

Kanter, R. M. (1977). Some Effects of Proportions on Group Life: Skewed Sex Ratios and Responses to Token Women In: The American Journal of Sociology, 82(5), S. 965-990. Im Internet unter: http://www. nhh. no/Files/Filer/adm/personal/Likestilling/MossKanter. pdf,[Zugriff: 02.02. 2008].

Kark, R., \& Shamir, B. (2013). The dual effect of transformational leadership: Priming relational and collective selves and further, effects on followers. In B. J. Avolio, \& F. J. Yammarino, Transformational and charismatic leadership: The road ahead 10th Anniversary Edition (pp. 77101). Bingley: Emerald Group Publishing Limited.

Kezar, A., \& Eckel, P. (2008). Advancing diversity agendas on campus: Examining transactional and transformational presidential leadership styles. International Journal of Leadership in Education, $11(4), 379-405$.

Kim, S., \& Park, S. (2017). Diversity Management and fairness in public organizations. Public Organization Review, 17(2), 179-193.

Konrad, A. M., Yang, Y., \& Maurer, C. C. (2016). Antecedents and outcomes of diversity and equality management systems: An integrated institutional agency and strategic human resource management approach. Human Resource Management, 55(1), 83-107.

Kossek, E. E., \& Lobel, A. (1996). Managing diversity. Oxford, UK: Blackwell Publishers.

Kossek, E. E., Markel, K. S., \& McHugh, P. P. (2003). Increasing diversity as an HRM change strategy. Journal of Organizational Change Management, 16(3), 328-352.

Lambert, J. (2016). Cultural diversity as a mechanism for innovation: Workplace diversity and the absorptive capacity framework. Journal of Organizational Culture, Communications and Conflict, 20(1), 68.

Larkey, L. K. (1996). Toward a theory of communicative interactions in culturally diverse workgroups. Academy of Management Review, 21(2), 463-491.

Leonard, A., \& Grebler, A. F. (2006). Exploring challenges to managing transformational leadership communication about employment equity: Managing organizational change in South Africa. Journal of Communication Management, 10(4), 390-406.

McKay, P. F., Avery, D. R., \& Morris, M. A. (2009). A Tale of Two Climates: Diversity Climate from Subordinates' and Managers' Perspectives and Their Role in Store Unit Sales Performance. Personnel Psychology, 62(4), 767-791.

McKay, P. F., Avery, D. R., Tonidandel, S., Morris, M. A., Hernandez, M., \& Hebl, M. R. (2007). Racial differences in employee retention: Are diversity climate perceptions the key? Personnel Psychology, 60(1), 35-62.

Meier, K. J., Wrinkle, R. D., \& Polinard, J. L. (1999). Representative bureaucracy and distributional equity: Addressing the hard question. The Journal of Politics, 61(4), 1025-1039.

Mor Barak, M. E., Cherin, D. A., \& Berkman, S. (1998). Organizational and personal dimensions in diversity climate: Ethnic and gender differences in employee perceptions. The Journal of Applied Behavioral Science, 34(1), 82-104.

Ng, E. S., \& Sears, G. J. (2012). CEO leadership styles and the implementation of organizational diversity practices: Moderating effects of social values and age. Journal of Business Ethics, 101(1), 41-52.

Nishii, L. H., \& Mayer, D. M. (2009). Do inclusive leaders help to reduce turnover in diverse groups? The moderating role of leader-member exchange in the diversity to turnover relationship. Journal of Applied Psychology, 94(6), 1412. 
Oliver, C. (1991). Strategic responses to institutional processes. Academy of Management Review, 16(1), 145-179.

Pitts, D. (2009). Diversity management, job satisfaction, and performance: Evidence from US federal agencies. Public Administration Review, 69(2), 328-338.

Robinson, G., \& Dechant, K. (1997). Building a business case for diversity. Academy of Management Perspectives, 11(3), 21-31.

Sashkin, M. (2004). Transformational leadership approaches. In J. Antonakis, A. T. Cianciolo, \& R. J. Sternberg, The nature of leadership (pp. 171-196). Thousand Oaks: Sage Publications.

Saxena, A. (2014). Workforce diversity: A key to improve productivity. Procedia Economics and Finance, 11, 76-85.

Seltzer, R. (2017, March 2). Failing to Keep. Inside Higher Ed. Retrieved from https://www.insidehighered.com/news/2017/03/02/racial-gap-among-senior-administratorswidens

Soni, V. (2000). A twenty-first-century reception for diversity in the public sector: a case study. Public Administration Review, 60(5), 395-408.

Tatum, B. C., Eberlin, R., Kottraba, C., \& Bradberry, T. (2003). Leadership, decision making, and organizational justice. Management Decision, 41(10), 1006-1016.

Thielemann, G. S., \& Stewart Jr, J. (1996). A demand-side perspective on the importance of representative bureaucracy: AIDS, ethnicity, gender, and sexual orientation. Public Administration Review, 168-173.

Thomas, D. A., \& Ely, R. J. (1996). Making differences matter. Harvard business review, 74(5), 79-90.

Tierney, W. G. (1991). Advancing democracy: a critical interpretation of leadership. Peabody Journal of Education, 66(3), 157-175.

Way, S. A., \& Johnson, D. E. (2005). Theorizing about the impact of strategic human resource management. Human Resource Management Review, 15(1), 1-19.

Wilson, L. (2009). Social inclusion in Australia: Resource allocation, morality, and racism. International Journal of Diversity in Organizations, 9(1), 165-174.

Wolverton, M., \& Gmelch, W. (2002). College Deans: Leading from Within. Washington, D.C.: ORYX/ACE Press.

Wright, P. M., \& Nishii, L. H. (2007). Strategic HRM and organizational behavior: Integrating multiple levels of analysis. CAHRS Working Paper Series, 468.

Zikic, J. (2015). Skilled migrants' career capital as a source of competitive advantage: Implications for strategic HRM. The International Journal of Human Resource Management, 26(10), 1360-1381.

Zohar, D. (2000). A group-level model of safety climate: testing the effect of group climate on microaccidents in manufacturing jobs. Journal of Applied Psychology, 85(4), 587. 